\title{
New data about the suspensor of succulent angiosperms: Ultrastructure and cytochemical study of the embryo-suspensor of Sempervivum arachnoideum $\mathbf{L}$. and Jovibarba sobolifera (Sims) Opiz
}

\author{
Malgorzata Kozieradzka-Kiszkurno • \\ Bartosz Jan Plachno • Jerzy Bohdanowicz
}

Received: 11 March 2011 / Accepted: 30 May 2011 /Published online: 5 June 2011

(C) The Author(s) 2011. This article is published with open access at Springerlink.com

\begin{abstract}
The development of the suspensor in two species Sempervivum arachnoideum and Jovibarba sobolifera — was investigated using cytochemical methods, light and electron microscopy. Cytological processes of differentiation in the embryo-suspensor were compared with the development of embryo-proper. The mature differentiated suspensor consists of a large basal cell and three to four chalazal cells. The basal cell produces haustorial branched invading ovular tissues. The walls of the haustorium and the micropylar part of the basal cell form the wall ingrowths typical for a transfer cells. The ingrowths also partially cover the lateral wall and the chalazal wall separating the basal cell from the other embryo cells. The dense cytoplasm filling the basal cell is rich in: numerous polysomes lying free or covering rough endoplasmic reticulum (RER), active dictyosomes, microtubules, bundles of microfilaments, microbodies, mitochondria, plastids and lipid droplets. Cytochemical tests (including proteins, insoluble polysaccharides and lipids are distributed in the suspensor during different stages of embryo development) showed the presence of high amounts of macromolecules in the suspensor
\end{abstract}

Handling Editor: Hanns H. Kassemeyer

M. Kozieradzka-Kiszkurno $(\bowtie) \cdot J$. Bohdanowicz

Department of Plant Cytology and Embryology,

University of Gdańsk,

Kładki 24 St.,

80-822 Gdańsk, Poland

e-mail: stokrota@biotech.ug.gda.pl

B. J. Płachno

Department of Plant Cytology and Embryology,

Jagiellonian University,

Grodzka 52 St.,

31-044 Krakow, Poland cells, particularly during the globular and heart-shaped phases of embryo development. The protein bodies and lipid droplets are the main storage products in the cells of the embryoproper. The results of Auramine 0 indicate that a cuticular material is present only on the surface walls of the embryoproper, but is absent from the suspensor cell wall. The ultrastructural features and cytochemical tests indicate that in the two species - S. arachnoideum and J. sobolifera - the embryo-suspensor is mainly involved in the absorption and transport of metabolites from the ovular tissues to the developing embryo-proper.

Keywords Crassulaceae - Cytochemistry - Embryo-proper . Specialised plastids $\cdot$ Suspensor differentiation .

Ultrastructure

\section{Introduction}

In many angiosperms, after fertilisation the zygote divides transversely to form a basal cell and an apical cell, which gives rise to the embryo-proper. The basal cell often creates a complete suspensor or only part of it (e.g., its basal cell). The suspensor is a variable and dynamic structure that performs important functions during plant embryogenesis (Yeung and Meinke 1993; Schwartz et al. 1997; Raghavan 2006). There is no typical angiosperm suspensor since the shape and size of suspensors varies widely between different species. A suspensor can consists of one single cell as in the nun orchid, Phaius tankervilliae (Ye et al. 1997), or several hundred cells as in Phaseolus coccineus (Yeung and Meinke 1993). The suspensor is a transient organ that performs a structural role by pushing the embryo-proper into the endosperm (Maheshwari 1950). 
Numerous studies on the cytochemistry (Pritchard 1964; Malik et al. 1977; Bohdanowicz 1987; KozieradzkaKiszkurno and Bohdanowicz 2006), ultrastructure (Clutter and Sussex 1968; Schulz and Jensen 1969; Schnepf and Nagl 1970; Bohdanowicz 1987; Lee et al. 2006) and biochemistry (Clutter et al. 1972; Walbot et al. 1972; Nagl 1977; Singh et al. 1980; Picciarelli et al. 1991) of the suspensor have indicated the probable role of the suspensor in the absorption, synthesis and/or translocation of nutrients from maternal tissue to the embryo-proper. The growth rate of the suspensor is often very rapid during earlier stages of embryogenesis. This embryonic organ usually degenerates at the later stages of embryo development (Raghavan 2006).

A family which has massive suspensors and poorly developed endosperm is the Crassulaceae. This is a family of dicotyledonous plants including herbs, subshrubs, and dwarf shrubs. Most species are succulents, that is, they are adapted to life in arid or waterless regions (Eggli 2003). Since the beginning of the 20th century, the Crassulaceae has attracted the attention of many researchers because of its interesting embryogenesis. The suspensor basal cell forms haustorial branches that invade the micropyle and adjacent tissues in this family. Many authors have described the structural aspects of embryogenesis but only at the level of the light microscope (Souéges 1927, 1936; Mauritzon 1933). Recently, some transmission electron microscopy (TEM) images of compound plasmodesmata (covered with unusual electron-dense material) in the embryo-suspensor of several Crassulaceae species: Sedum acre, S. hispanicum (Kozieradzka-Kiszkurno and Bohdanowicz 2010), Sempervivum arachnoideum and Jovibarba sobolifera (KozieradzkaKiszkurno et al. 2011) have been published, but without details of the ultrastructure of this embryonic organ. The species $S$. arachnoideum and J. sobolifera were chosen for this study because both are native representatives of Polish flora. In addition, both species are quite morphologically different from the species from the Sedum genus that were studied earlier. We prefer native species, which grow in natural or semi-natural conditions, so that weather/growing conditions will not have an influence on generative reproduction. Moreover, we had studied the plasmodesmata structure earlier so it was interesting to connect these results with the general ultrastructure of the suspensor. In Crassulaceae, the suspensor basal cell forms special haustorial protrusions, which penetrate the ovular tissues, and are apparently the main source of nutritive substances for the embryo-proper. These studies are a part of many years of research conducted by the first author on the functional ultrastructure of the suspensor - highly endopolyploid cells of the embryo sac.

It should be highlighted that this is the first report to describe the ultrastructural changes in the embryosuspensor during embryogenesis in Crassulaceae. The results of our detailed study of the ultrastructure and cytochemistry of embryo-suspensor in S. arachnoideum L. and $J$. sobolifera (Sims) Opiz are reported here, and its possible roles in embryogenesis are discussed.

\section{Materials and methods}

Plant material

Plants of S. arachnoideum L. at different stages of development were obtained from a commercial company (http://kaktusiarnia.pl/index1.html) in northern Poland. Inflorescences of $J$. sobolifera (Sims) Opiz were collected from its natural habitat in Kokotek near Lubliniec in the south of Poland. Several additional plants were also obtained from the Botanic Garden of the Jagiellonian University, Krakow, Poland.

\section{Electron microscopy}

For electron microscopy, the ovules at different stages of embryo development were fixed in $2.5 \%$ formaldehyde (prepared from paraformaldehyde) and $2.5 \%$ glutaraldehyde in a $0.05 \mathrm{M}$ cacodylate buffer $(\mathrm{pH}=7.0)$ for $4 \mathrm{~h}$ at room temperature. The material was subsequently rinsed in the same buffer and post-fixed in $1 \%$ osmium tetroxide in a cacodylate buffer at $4{ }^{\circ} \mathrm{C}$ overnight. Specimens were treated with $1 \%$ uranyl acetate in distilled water for $1 \mathrm{~h}$, dehydrated in a graded acetone series and embedded in Spurr's resin (Spurr 1969). Serial ultrathin $(60-100 \mathrm{~nm})$ sections were cut with a diamond knife on a Sorvall MT 2B microtome and then post-stained with a saturated solution of uranyl acetate in $50 \%$ ethanol and with $0.04 \%$ lead citrate. Observations were made using a Philips CM 100 transmission electron microscope operating at $80 \mathrm{kV}$.

\section{Cytochemistry}

For light microscopy, semithin sections $(0.5-1.5 \mu \mathrm{m})$ were stained with $0.05 \%$ toluidine blue 0 in $1 \%$ sodium tetraborate. For cytochemical observations, sections were stained with periodic acid-Schiff (PAS) for the localisation of insoluble polysaccharides (Jensen 1962), with Aniline Blue Black for proteins (Jensen 1962), and with Sudan Black B for lipids (Bronner 1975). Fresh embryos at different stages of development were dissected from living ovules and placed in a drop of fluorochrome Auramine 0 solution. The presence of cuticle was observed with Auramine 0 staining (Heslop-Harrison 1977). Sections were examined and photographed with a Nikon Eclipse E 800 microscope equipped with a Nikon cooled CCD camera. 


\section{Results}

Both S. arachnoideum and J. sobolifera undergo the Caryophyllad type of embryonic development (Fig. 1a, b). The development of the embryo-suspensor in these species is very similar, therefore the results will be described together. After the first division of the zygote, two cells of unequal size are formed: a large basal cell and a smaller apical one. The basal cell undergoes no division, becomes much enlarged and produces haustorial branches that invade the micropyle and adjacent tissues. The apical cell develops into the embryo-proper and chalazal suspensor. Differentiation of the suspensor in both species was studied in comparison with the development of the embryo-proper.

\section{Globular-stage embryo}

At this phase of development, the suspensor is well differentiated in both species. The suspensor consists of a very large basal cell with the micropylar haustorium (MH) and a few chalazal cells (Fig. 2a, b). This huge basal cell $(\sim 70 \times 38 \mu \mathrm{m})$ contains a single large nucleus containing one dense nucleolus, which is situated in the central part of the basal cell. The cell walls of the suspensor and the embryo-proper are clearly PAS-positive. The micropylar part of the basal cell wall produces delicate PAS-positive ingrowths (Fig. 2c). The basal cell contains a large quantity of proteins and is weakly vacuolised in comparison with the remaining cells of the embryo (Fig. 2d). Numerous lipid droplets are visible throughout the basal cell. Occasionally, lipids are also present in the chalazal suspensor cells and in the cells of the embryo-proper (Fig. 2e). The positive staining of Auramine 0 in the embryo-proper in the both species indicates the presence of cuticular substances in the wall. On the outer surfaces of the embryo-proper, there is a thin cuticle; however, it is absent in the suspensor (Fig. 2f). Ultrastructural observations indicate that an electron-dense cuticular layer accumulates on the surface of walls of the embryo-proper (Fig. 2g).

The basal cell is anchored to the micropylar end of the embryo sac. At this stage of development, the $\mathrm{MH}$ of the basal cell is already strongly developed and ramifies in the integumentary tissue. The cytoplasm of the basal cell is filled with the profiles of endoplasmic reticulum, dictyosomes, plastids, mitochondria, microbodies, lipid droplets and vacuoles (Fig. 3a). The micropylar part of the basal cell wall forms ingrowths. Generally, the ultrastructure of the wall ingrowths is typical for transfer cells; the plasmalemma follows the contours of the ingrowths closely. The mitochondria are spherical to ellipsoidal in shape. They are the most numerous of the organelles and occur throughout the cytoplasm. They have well-developed cristae (Fig. 3b). At this phase of development, microtubules and microfilaments are occasionally found near to the cell wall. Single cisternae of the RER are distributed fairly evenly throughout the basal cell (Fig. 3a, b). The dense cytoplasm of the basal cell contains numerous ribosomes which occur in polysomal aggregates and may be free or attached to membranes of the rough endoplasmic reticulum (RER). At this stage, the cytoplasm of the basal cell has a welldeveloped smooth endoplasmic reticulum (SER). The suspensor plastids are quite different from those of the
Fig. 1 General structure of the Crassulacean ovule and embryo. a Semithin section through the ovule of Jovibarba sobolifera showing the relation between the embryo-proper, the suspensor, the haustorium of the basal cell, the endosperm and integument tissues. Scale bar: $25 \mu \mathrm{m}$. b Schematic reconstruction of the suspensor haustorium and the embryo-proper based on several semithin sections. 1 micropylar haustorium, 2 basal cell, 3 chalazal suspensor cells, 4 embryo-proper, 5 endosperm, 6 internal integument, 7 external integument

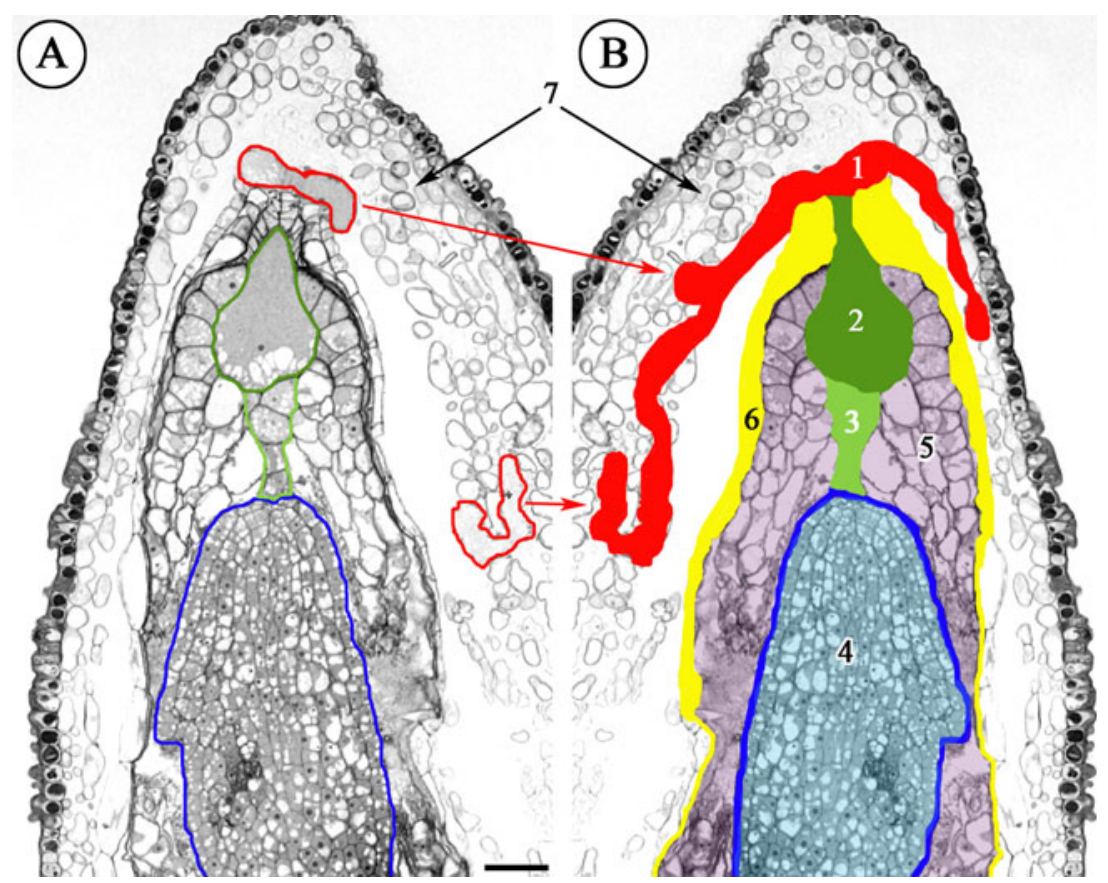




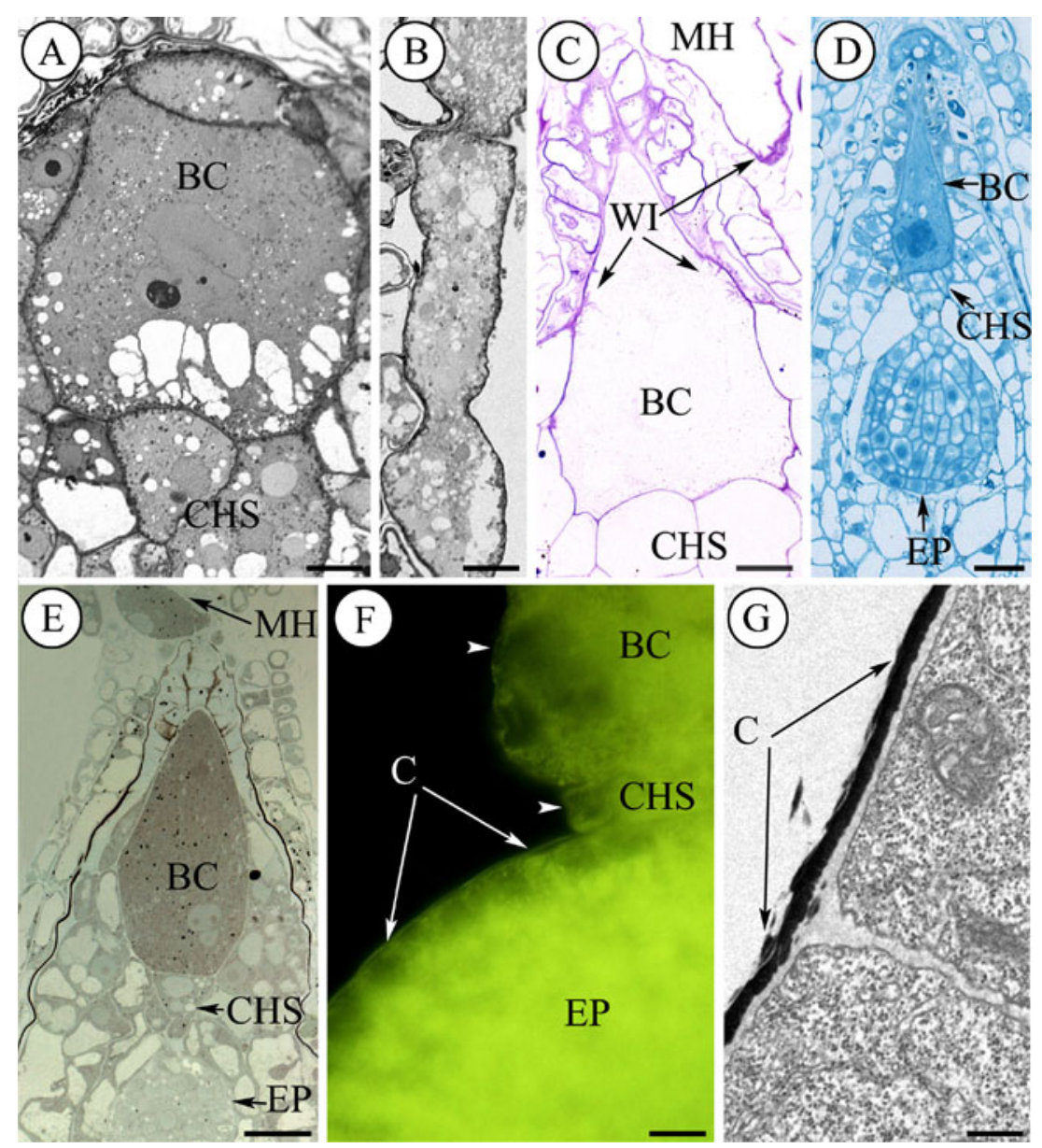

Fig. 2 Globular stage of the development of the embryo-suspensor Sempervivum arachnoideum (a-d) and J. sobolifera (e-g). Results of cytochemical tests. (a-f) Light micrographs, g Electron micrograph. a Semithin section showing the large basal cell $(B C)$ and two chalazal cells $(C H S)$. Scale bar: $10 \mu \mathrm{m}$. b Fragment of the micropylar haustorium of the basal cell. Scale bar: $10 \mu \mathrm{m}$. c Embryo-suspensor stained for polysaccharides. Note the PAS-positive ingrowths $(W I)$ of the $\mathrm{BC}$ and the micropylar haustorium $(M H)$; the CHS. Scale bar: $10 \mu \mathrm{m}$. d Embryo-suspensor stained with Aniline Blue Black showing

embryo-proper. Plastids are considerably larger than mitochondria and are distributed randomly throughout the basal cell. They are irregular in shape and are poorly differentiated. They are filled with a matrix of low density with very small tubules, sometimes a few internal membranes and occasionally a few plastoglobuli (Fig. 3b). In addition, a few microbodies are present in the cytoplasm of the basal cell. They are bounded by a single membrane and exhibit a uniform electron-dense matrix. Usually microbodies occur in close association with the cisternae RER. The wall separating the basal cell from the chalazal suspensor cells contains numerous plasmodesmata. There are a large number of plasmodesmata in the thin inner walls of the chalazal suspensor and the embryo-proper. They are absent in the outer walls of the whole embryo-proper. The chalazal suspensor cells, linking the basal cell with the embryo- the distribution of proteins; the $\mathrm{BC}$, chalazal suspensor cells $(C H S)$, the embryo-proper $(E P)$. Scale bar: $25 \mu \mathrm{m}$. e Section stained with Sudan Black B showing the location of lipid droplets; the BC, the $\mathrm{MH}$, the CHS and the EP. Scale bar: $25 \mu \mathrm{m}$. f Cuticle fluorescence after Auramine 0 treatment. Fragment of the EP with the fluorescing cuticle $(C)$ (arrows). Note that the fluorescence of the suspensor walls is absent (arrowheads); the BC, the CHS. Scale bar: $50 \mu \mathrm{m}$. g Portion of the embryo-proper with electron-dense layer cuticle $(C)$. Scale bar: $250 \mathrm{~nm}$

proper, consist of a few cells. Ultrastructurally these cells are similar to the cells of the embryo-proper.

\section{Heart and late heart-stage embryos}

The ultrastructure and cytochemistry of the heart and late heartstage embryos are similar enough that these stages may be described together. When the embryo-proper reaches these stages, the basal cell undergoes full development. The fully developed suspensor consists of a large basal cell $(\sim 90 \times 50)$ and two to four chalazal cells (Fig. 4a). As compared with the previous stage of development, the number and size of wall ingrowths increase. They are branched and PAS-positive. The ingrowths extend over the entire micropylar half of the cell wall. Similar ingrowths form on the chalazal wall that separates the basal cell from the other embryo cells. The 
Fig. 3 Globular stage of the development of the embryosuspensor in $J$. sobolifera. Electron micrographs: a The micropylar part of the basal cell showing the formation of the wall ingrowths $(W I)$ along the basal wall. The cytoplasm of the basal cell is rich with mitochondria $(M)$, profiles of endoplasmic reticulum $(E R)$, dictyosomes $(D)$. Scale bar: $1 \mu \mathrm{m}$. b Portion of the basal cell cytoplasm. Note numerous mitochondria, profile of the endoplasmic reticulum $(R E R)$, a giant irregular-shaped plastid $(P)$, microbodies $(M B)$, lipid droplets $(L)$ and vacuoles $(V)$. Scale bar: $500 \mathrm{~nm}$
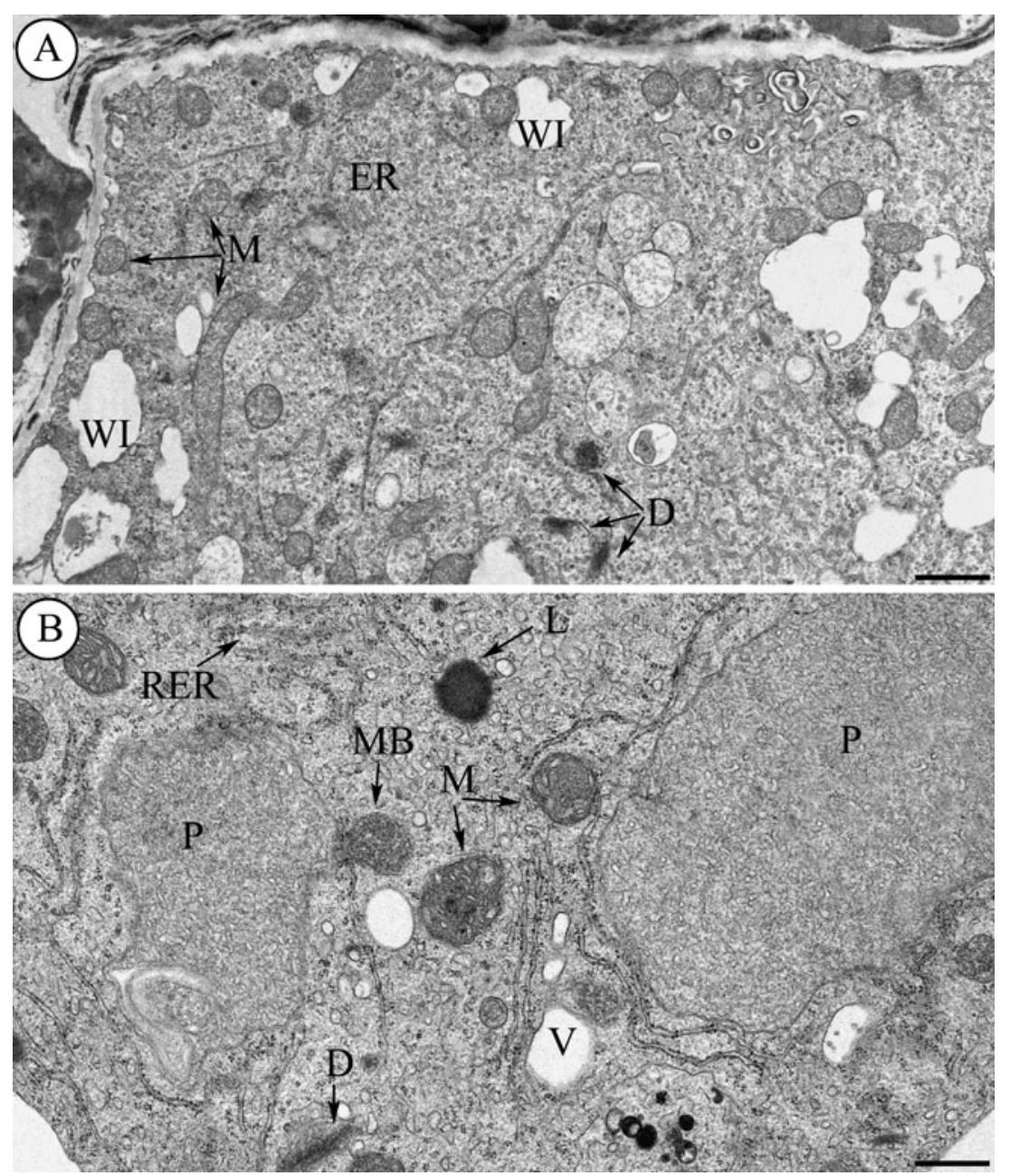

lateral walls that separate the cell from the endosperm are thinner and covered with single wall ingrowths (Fig. 4b). Occasionally, lipids are present in the basal cell and in the micropylar haustorium. There is an increase in the number of lipid droplets, particularly in the chalazal suspensor cells, the embryo-proper and the endosperm (Fig. 4c). The embryoproper has abundant storage materials deposited in the form of lipids (Fig. 4d) and protein bodies (Fig. 4e) in the cytoplasm. Ribosome density is lower in the suspensor than in the embryo-proper. The protein content of the cytoplasm in the basal suspensor cell is distinctly lower than in the chalazal suspensor cells and the embryo-proper (Fig. 4f). Similar to the previous stage of development there is a thin cuticle on the outer surfaces of the embryo-proper however it is absent in the suspensor (Fig. 4g). At this stage of development, the plastids are the most prominent organelles within the basal cell (Fig. 5a) and the micropylar haustorium. The plastids of the suspensor cells undergo developmental changes and these are of special interest. These organelles are irregular in shape. They become more electron-dense and often have numerous lamellae. Occasionally, two types of inclusions: electron- lucent and electron-dense appear in some plastids. The RER cisternae are more numerous than at the previous stage and are often arranged parallel to each other (Fig. 5a). Another notable feature at this stage of development was the abundance of SER cisternae throughout the basal cell. As compared with the previous stage of development, dictyosomes are more numerous in the cytoplasm (Fig. 5a). Dictyosomes have an active appearance with five or six cisternae and many vesicles associated with them. These organelles are distributed throughout the cell with a large number concentrated near the wall ingrowths. At this phase of development, like in the previous stage, mitochondria are the most numerous of the organelles and occur throughout the cytoplasm (Fig. 5a, b). In particular, many mitochondria concentrate near to the wall ingrowths. The plasmodesmata with dense material are well visible near wall ingrowths (Fig. 5b and inset). Ribosome density is lower in the basal cell than in the chalazal suspensor cells. Generally, plastids in the chalazal suspensor cells are much smaller than those found in the basal cell and have a more regular shape. Some of these plastids contain lamellae (Fig. 5b). 
Fig. 4 The heart and late heartstage embryos of the development of the embryo-suspensor of $J$. sobolifera. $(\mathbf{a}-\mathbf{c}, \mathbf{f}, \mathbf{g})$ Light micrographs; (d, e) electron micrographs. a A longitudinal section showing the large $\mathrm{BC}$, CHS and portion of the EP.

Scale bar: $10 \mu \mathrm{m}$. b Section stained for polysaccharides. The micropylar end of the $\mathrm{BC}$ wall and the $\mathrm{MH}$ form extensive PAS-positive ingrowths; the CHS. Scale bar: $25 \mu \mathrm{m}$. c Section stained with Sudan Black B showing the distribution of lipid droplets; the $\mathrm{BC}$, the CHS, the EP. There is an increase in the number of lipid droplets, particularly in the CHS and the EP; the BC. Scale bar: $50 \mu \mathrm{m}$. d Portion of the cells of the embryo-proper showing numerous of lipid droplets $(L)$. Scale bar: $2 \mu \mathrm{m}$, e Portion of cells of embryo-proper of the middle and lower parts showing the protein bodies $(P B)$. f Section stained with Aniline Blue Back showing protein distribution; the $\mathrm{BC}$, the CHS; the EP. Scale bar: $25 \mu \mathrm{m}$. g Fragment of the embryo-proper. The fluorescing cuticle $(C)$ is visible on the surface of the embryoproper. Scale bar: $50 \mu \mathrm{m}$

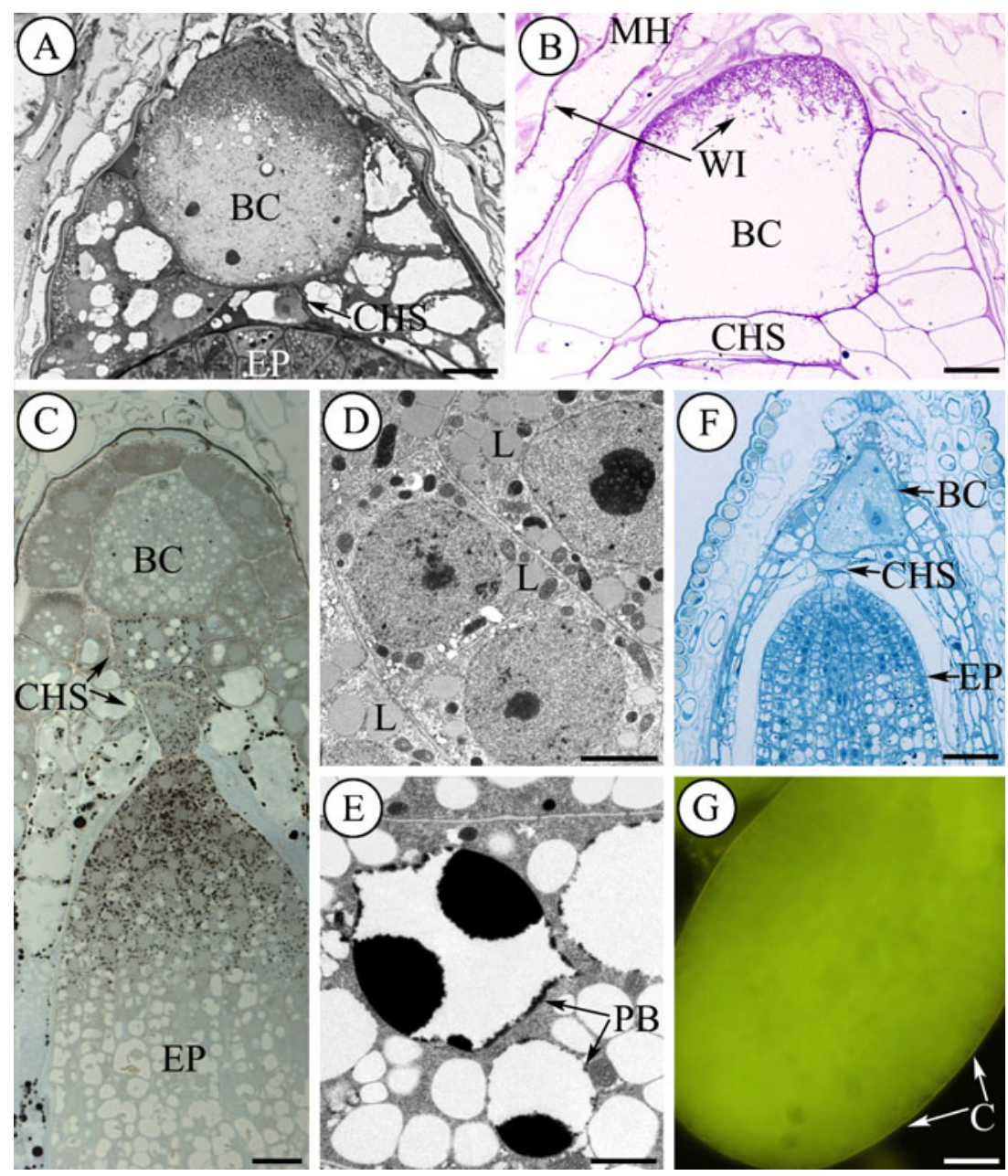

The haustorium of the basal cell

The haustorium of the basal cell is observed at an early globular embryo stage. The basal cell of the suspensor increases in size during the development of the embryoproper. Together with the enlargement of the basal cell, its micropylar haustorium grows and gradually penetrates more deeply into the integument tissue (Figs. 1a,b, 6a and 7a). Delicate PAS-positive ingrowths are formed on the young micropylar haustorium wall: they enlarge in the later stages of development and therefore the plasmalemma surface increase (Figs. 2c, $4 \mathrm{~b}$ and $6 \mathrm{~d}$ ). In the early development, the micropylar haustorium contains a large quantity of proteins and is weakly vacuolized in comparison with the remaining cells of the embryo (Fig. 2d). Numerous lipid droplets are visible (Fig. 2f). At the tip of the basal cell prior to intruding through the integument there is a very dense cytoplasm with only a few organelles. It should especially be noted that numerous profiles of endoplasmic reticulum (RER) are oriented parallel to the long axis of the basal cell (Fig. 6b). The haustorium has rare cytoplasm. The cytoplasm of haustorium is rich with mitochondria, a single cisternae of the endoplasmic reticulum, dictyosomes and large plastids (Fig. 6c, d). The haustorium penetrates the external integument tissue, which has a very loose structure and contains many intercellular spaces (Figs. 1a,b and 7a). The integument cells contain numerous lipid droplets (Fig. 2e) and starch grains. Instead of contact between the haustorium and integument cells, crushed cells are observed (Fig. $7 b, c)$. Between the haustorium and integument cells, neither the cuticular material (which occurs between the embryo-proper and endosperm cells) nor plasmodesmata can be seen (Fig. 7d).

\section{Discussion}

The suspensor of $S$. arachnoideum and J. sobolifera, in particular its basal cell, undergo developmental changes during the process of embryogenesis. The role of the suspensor in nutrient transport to the embryo-proper is confirmed by the structure of the basal cell. 
Fig. 5 The heart and late heartstage embryos of the development of the embryo-suspensor of $S$. arachnoideum. a, b Electron micrographs. a The basal cell contains a large nucleus $(N)$ and two nucleoli $(N U)$. The cytoplasm is filled with RER cisternae that are often arranged parallel to each other, dictyosomes $(D)$; plastid $(P)-$ electron-lucent and electrondense inclusions, vacuoles $(V)$, lipids $(L)$. Scale bar: $1.5 \mu \mathrm{m}$ b Part of the wall $(W)$ between the $\mathrm{BC}$ and the first layer of the CHS. Ribosome density is lower in the basal cell than in the chalazal suspensor cells. The wall of the chalazal suspensor cells forms ingrowths $(W I)$. The cytoplasm of the chalazal suspensor cells is strongly vacuolized. Note the numerous mitochondria, dictyosomes and less numerous electron-dense plastids $(P)$; nucleus $(N)$, nucleolus $(N U)$, vacuoles $(V)$. Inset: high magnification of the plasmodesma. Scale bar: $1 \mu \mathrm{m}$
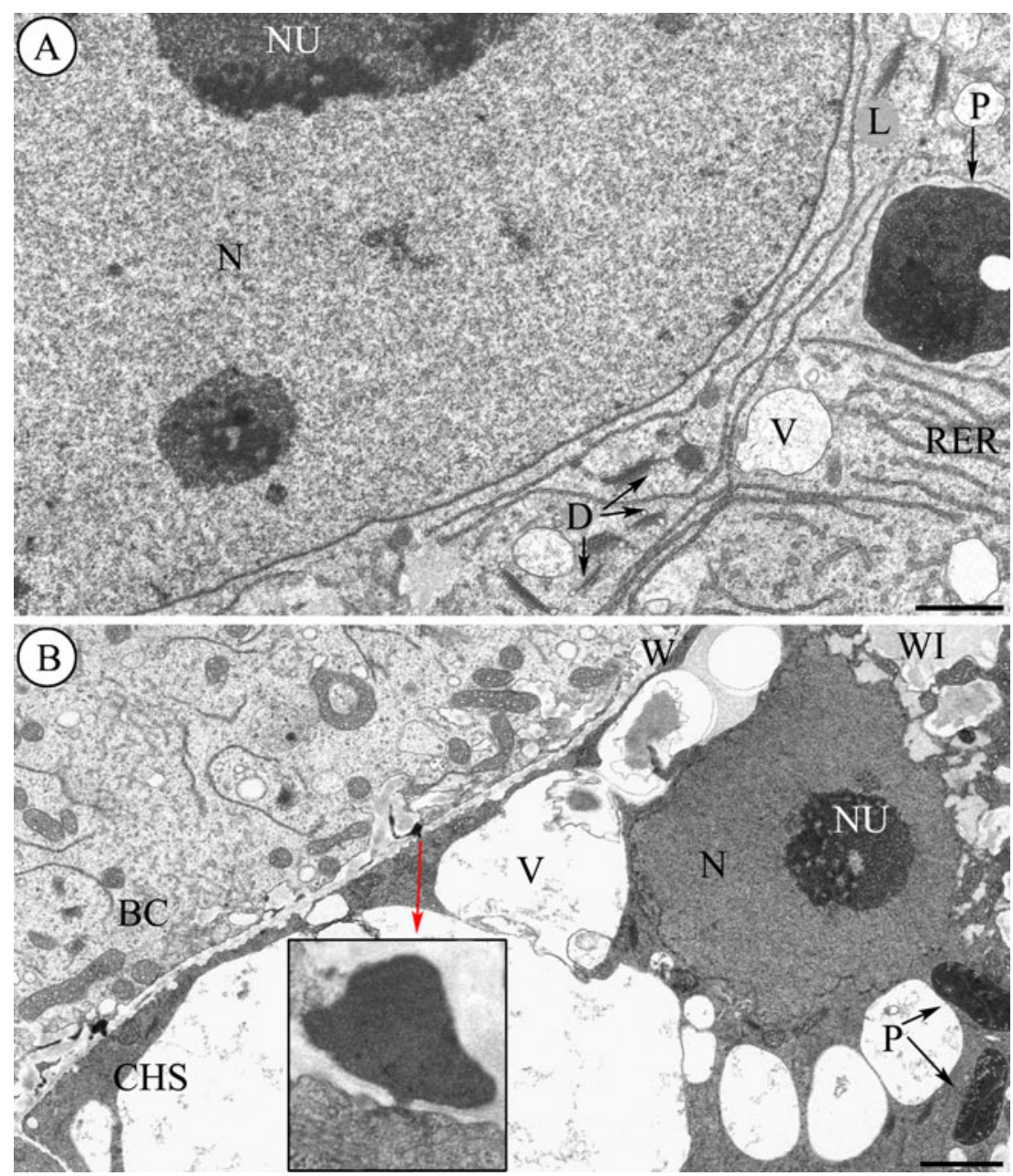

The basal suspensor cell as a transfer cell

An especially fascinating feature of the suspensor cells is the presence of wall ingrowths (Raghavan 2006). Wall ingrowths have been observed in many plant cells which are actively engaged in absorption and secretion ("transfer cells"; Gunning and Pate 1969). In Crassulaceae, the suspensor basal cell produces haustorial protrusions that penetrate the ovular tissues, and is the main source of nutritive substances for the embryo-proper. In S. arachnoideum and J. sobolifera the suspensor precedes the embryo- proper as well as the endosperm in development. This suggests that in the early stages of embryogenesis the suspensor functionally replaces the poorly developed endosperm in nutrition of the embryo proper. The micropylar part of the suspensor basal cell and micropylar haustorium in the both of species is covered with wall ingrowths typical of transfer cells. These wall ingrowths, which are surrounded by a plasma membrane, greatly increase the ability of these cells to absorb nutrients from surrounding tissues (Pate and Gunning 1972). Wall ingrowths have been found in the suspensor cells of many species: Phaseolus (Clutter and Sussex 1968; Schnepf and
Nagl 1970; Nagl 1974; Yeung and Clutter 1979), Capsella (Schulz and Jensen 1969), Pisum (Marinos 1970), Epilobium, Antirrhinum, Vicia, Lathyrus, Scrophularia (Gunnung and Pate 1974), Stellaria (Newcomb and Fowke 1974), Diplotaxis (Simoncioli 1974), Tropaeolum (Nagl 1976), Alyssum (Prabhakar and Vijayaraghavan 1983), Medicago (Sangduen et al. 1983), Alisma (Bohdanowicz 1987), Paphiopedilum delenatii (Lee et al. 2006), Sedum acre and S. hispanicum (Kozieradzka-Kiszkurno and Bohdanowicz 2006). Along with the formation of wall ingrowths in the suspensor cells in $S$. arachnoideum and $J$. sobolifera, there is a concomitant increase in the number of mitochondria. The cytoplasm of the suspensor and the micropylar haustorium contains numerous mitochondria, particularly in the neighborhood of the wall ingrowths, which suggests an energy requiring process, presumably the transport of solutes across the plasmalemma. The wall ingrowths of the transfer cells develop during the early stages of embryogenesis and are most extensive by the late heart stage in both species. Similar suggestions have been made for the wall ingrowths occurring in: Capsella bursa-pastoris (Schulz and Jensen 1969), Diplotaxis erucoides (Simoncioli 1974), P. coccineus (Yeung 
Fig. 6 Globular stage of the development of the embryosuspensor of $J$. sobolifera. a Light micrograph, $\mathbf{b}-\mathbf{d}$ electron micrographs. a A longitudinal section stained with toluidine blue 0 . Fragment of the $\mathrm{BC}$ with a well-developed $\mathrm{MH}$, integument $(I N)$, endosperm $(E N)$. Scale bar: $10 \mu \mathrm{m}$. b A higher magnification of the tip of the basal cell from a mitochondrion $(M)$, dictyosome $(D)$, plastid $(P)$, profiles of the endoplasmic reticulum $(R E R)$. Scale bar: $500 \mathrm{~nm}$. c The micropylar haustorium of the basal cell is filled with electron-loose cytoplasm containing ribosomes, mitochondria $(M)$, giant plastids $(P)$, a single profiles of the RER, microbodies $(M B)$. Scale bar: $500 \mathrm{~nm}$. d A fragment of the basal cell haustorium showing wall ingrowths $(W I)$, haustorium wall $(W)$ and mitochondria $(M)$. Scale bar: $1 \mu \mathrm{m}$
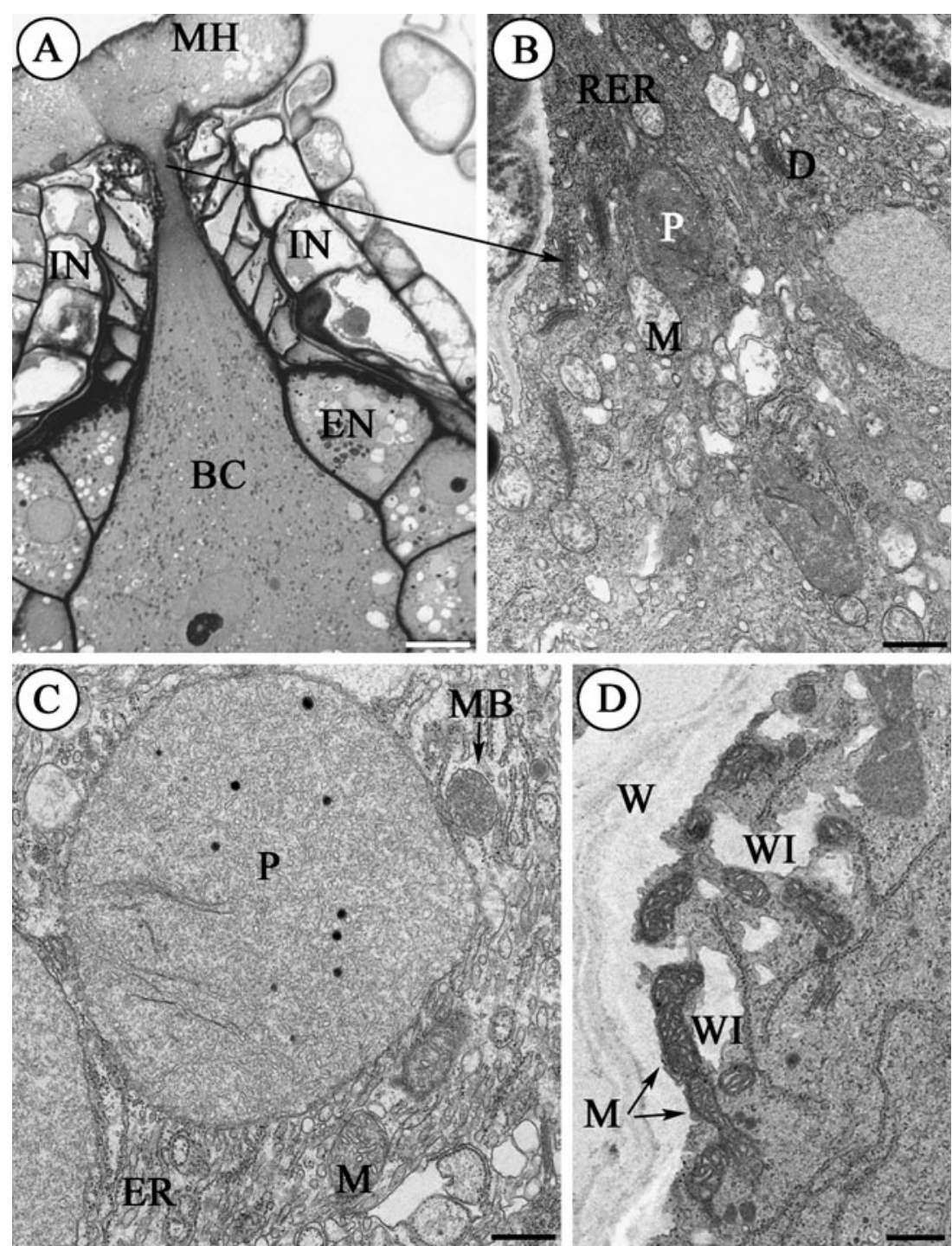

and Clutter 1979), Alisma (Bohdanowicz 1987) and Paphiopedilum delenatii (Lee et al. 2006). Our ultrastructural study also indicates the presence of microfilaments and microtubules near the wall ingrowths in the basal cell as well as in the micropylar haustorium. The presence of cytoskeletal components bordering wall ingrowths has been documented by some authors (Jones and Northcote 1972; Cass and Karas 1974; Świerczyńska and Bohdanowicz 2003; KozieradzkaKiszkurno et al. 2010; Płachno et al. 2010) but their precise role in establishing transfer cell morphology has yet to be established. The role of the suspensor in metabolite transport is underlined by the presence of plasmodesmata. According to the results of our observation, both studied species have numerous plasmodesmata in the chalazal end wall of the basal cell and in the end walls of the suspensor cells, which is evidence of the flow of substances between these cells and the growing embryo-proper. Plasmodesmata are absent from the outer walls of the embryo. A similar distribution of plasmodesmata was observed in the suspensors of: Alisma, Capsella, Helianthus, Diplotaxis. Recently, we found that in some species from the Crassulaceae family (Sedum acre, $S$. hispanicum, $S$. arachnoideum and J. sobolifera) the size of the diameter of plasmodesmata varies according to the micropylar-chalazal axis of the embryo. We found that the largest diameter of plasmodesmata occurred between the giant basal cell and chalazal suspensor cells. A smaller diameter of plasmodesmata occurred between the chalazal suspensor cells and the cells of the embryo-proper, and the smallest diameter of plasmodesmata between embryo-proper cells (Kozieradzka-Kiszkurno et al. 2011).

The basal suspensor cell as a metabolic site

The results of cytochemical tests on the composition and distribution of proteins, insoluble polysaccharides, lipids and cuticular materials at various stages of the development 


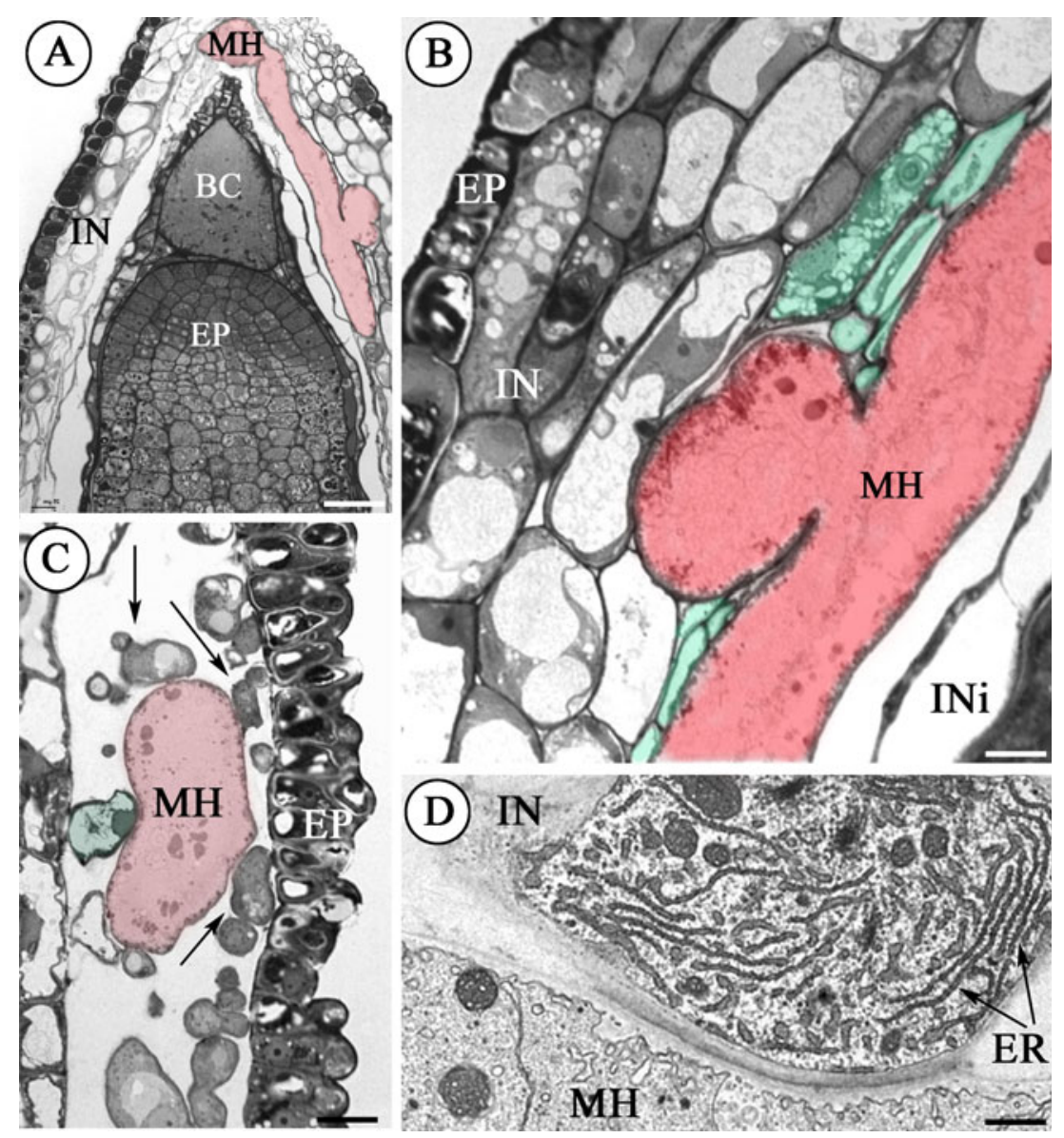

Fig. 7 Heart and late heart-stage embryos of the development of the embryo-suspensor of $S$. arachnoideum. a-c Light micrographs, d electron micrograph. a A Longitudinal section showing the large $\mathrm{BC}$, the haustorium $(M H)$ (red colored) and a portion of the embryoproper $(E P)$. Scale bar: $25 \mu \mathrm{m}$. b A higher magnification of the portion of the haustorium and integument tissue; the external integument epidermis $(E P)$, external integument cells $(I N)$, internal integument cells $(I N i)$. The integument cells which have structural changes or are crushed by the developing haustorium are marked in green. Scale bar: $10 \mu \mathrm{m}$. c A portion of external integument tissue $(E P)$ with the haustorium of the basal cell; two different behaviors of the cells in contact with the haustorium: a degenerating cell (marked in green), active cells with "healthy" cytoplasm (arrows). Scale bar: $10 \mu \mathrm{m}$. d A contact between haustorium of the basal cell $(M H)$ and integument cell $(I N)$; profiles of endoplasmic reticulum $(E R)$. Scale bar: $500 \mathrm{~nm}$ of embryo-proper and the suspensor, and an analysis of the suspensor ultrastructure in $S$. arachnoideum and J. sobolifera, confirm that the basal cell is the site of intense metabolic activity. The ultrastructure of various organelles present in the suspensor suggest that this embryonic organ may be the site of metabolism that does not occur within the embryo-proper. The SER appears early in the development of the embryo in $S$. arachnoideum and $J$. sobolifera similar to that observed in the suspensor cells of Stellaria media (Newcomb and Fowke 1974), P. coccineus (Yeung and Clutter 1979) and Paphiopedilum delenatii (Lee et al. 2006). The SER has been found near the wall ingrowths in both species, which indicates that it may provide a more efficient mechanism for solute transport (Schulz and Jensen 1969; Newcomb and Fowke 1974). Biochemical analysis suggests that the endoplasmic reticulum (ER) may function directly in the synthesis and secretion of secondary wall materials (Westafer and Brown 1976). A large number of dictyosomes have been found near to the developing ingrowths in: Capsella, Diplotaxis, Phaseolus, Stellaria (Raghavan 2006). Such images have also been noted in the suspensors of $S$. arachnoideum and $J$. sobolifera It is generally recognised that dictyosome vesicles may participate in the export of material comprising wall ingrowths. According to Raghavan (1997), the suspensor is the main source of growth regulators for the embryo-proper in early embryogenesis. The presence of extensive SER in Phaseolus suspensors is associated with the metabolic function of gibberellin biosynthesis. RER is associated with intense protein synthesis (Gunning and Steer 1975). The significant amounts of cytochemically detected protein in the cytoplasm of the basal cell of $S$. arachnoideum and $J$. sobolifera seem to confirm this interpretation of the function of the RER here. The 
frequency of polysomes in both species suggests active protein synthesis, which would be necessary for rapid growth of the suspensor basal cell. The occurrence of lipid droplets in the cytoplasm of both the haustorial suspensor and the embryo-proper is probably due to its rich, tubular SER. The endoplasmic reticulum participates in the synthesis and secretion of lipids. The ER is also equipped with the enzymes and structural proteins involved in the biogenesis of oil bodies and the storage of lipids. Microbodies are not very numerous in the suspensor and micropylar haustorium of $S$. arachnoideum and J. sobolifera and they are not found in the embryo-proper. Most microbodies contain at least part of either the glycolate pathway or the glyoxylate cycle. Thus, it appears likely that these organelles may be important metabolically. The presence of important metabolic enzymes has been found in plant microbodies (Tolbert 1971; Gunning and Steer 1975; Tolbert and Essner 1981). Another common subcellular feature present in the suspensor cells of flowering plants is the presence of specialised plastids. Specialised plastids that have been described in the suspensors of Pisum (Marinos 1970), Ipomoea (Ponzi and Pizzolongo 1973), Stellaria (Newcomb and Fowke 1974), Tropaeolum (Nagl and Kühner 1976), Medicago (Sangduen et al. 1983), Alisma (Bohdanowicz 1987), Vicia faba (Johansson and Walles 1993) and Paphiopedilum delenatii (Lee et al. 2006), although differing in details, are somewhat analogous to those observed in $S$. arachnoideum and $J$. sobolifera. We observed a notable change in the suspensor plastids in the heart embryos. The plastids become strongly electron-dense. They contain tubular structures and two types of inclusion as in Stellaria (Newcomb and Fowke 1974) and Medicago (Sangduen et al. 1983), that are not present in plastids in the embryo-proper. The role of these unusual organelles remains to be investigated; they may play a function in the synthesis of compound nutrients and/or substances which control the development of the embryo-proper. The presence of a large amount of SER and specialised plastids in the suspensor cells and their absence in the embryo-proper further confirm the unique nature of the embryo-suspensor. Some investigations regarding the development of the embryo in angiosperms have indicated the presence of cuticular substances on the surface of the embryo-proper and their absence in the suspensor wall (Rodkiewicz et al. 1994; Lee et al. 2006). Our observation on the presence a fluorescing cuticle on the developing $S$. arachnoideum and $J$. sobolifera embryos also indicates the absence of cuticular substances in the suspensor wall. The results of these studies clearly confirm the structural and functional differences between the suspensor and embryo-proper. Furthermore, the absence of cuticular substances in the suspensor would allow for apoplastic continuity between the maternal tissues and the embryo and thereby facilitate nutrient movement from the maternal tissues to the embryo via the suspensor. On the other hand, the presence of cuticular substances in the wall of the embryo proper may create a protective covering for the embryo from early desiccation.

\section{Suspensor haustoria}

Suspensor haustoria have been detected in 16 families of Angiosperms besides Crassulaceae (Mauritzon 1933), e.g., Orchidaceae, Rubiaceae, Acanthaceae, Tropaeolaceae, Podostemaceae (Mikesell 1990). Within Crassulaceae, there is diversity in the development of suspensor haustoria. For example in Jovibarba, Sempervivum, haustoria invade the integuments. However, in some species of Sedum, the haustorium not only penetrates the integument but also invades the funiculus, which is where vascular tissue occurs (Johri and Ambegaokar 1992). In Pistorinia hispanica, the haustorium even grows on the external surface of the external integument (Johri and Ambegaokar 1992). It is worth considering why the basal cell extends the micropyle and invades the integument tissues. The explanation might be that there is a lack of the thick cuticle-like barrier between the suspensor haustorium and the integuments. If the suspensor haustorium invades the endosperm, it would be limited by the thick layer of cutin-like material which occurs between the endosperm/integument. Thus, the easiest way is for it to grow outside the micropyle and to later invade the less protected integument tissue. In addition, it was also found that there is an accumulation of nutrients/metabolites in the integument tissues (Shamrov 2000), with which our results agree. According to Chamberlin et al. (1993), there is an accumulation of labeled assimilates in the integumentary tissue adjacent to the micropylar and chalazal poles of the embryo sac. The authors suggested that the chalazal vascular trace and two adfunicular vascular strands are the pathways for the accumulation of the labeled assimilates in these regions of the ovule. Further proof that the haustorium is the path of nutrient flow from integuments to the embryo is the wall ingrowths that occur on the cell walls of the haustorium. Due to the lack of the plasmodesmata in the walls bordering the haustorium and integument cells the nutrient must be transported in an apoplastic way using wall ingrowths. However, later the nutrient can be transported in two different ways from the basal cell to the other over suspensor cells: the apoplastic way through the cell walls and the symplasmic way transport through plasmodesmata. There are developmental changes in the structure of the plasmodesmata in the Crassulacean suspensor. In the juvenile phase (two-celled embryo), there are simple plasmodesmata, and later during embryogenesis in the suspensor, the plasmo- 
desmata branch (Kozieradzka-Kiszkurno 2003). This maturation of the plasmodesmata might be connected with the growing demand for nutrients of the embryo-proper.

\section{Conclusion}

The results of our cytochemical and ultrastructural investigations have indicated that the suspensor basal cells of both species function as a synthetically active transfer cell that absorbs nutrients from maternal tissues, metabolising and translocating them through the chalazal suspensor cells to the embryo-proper.

Acknowledgements We cordially thank the director of the Botanic Garden of the Jagiellonian University, Prof. Bogdan Zemanek, and the supervisor of Botanic Garden (Chief Gardener), Maria Uzarowicz, for granting us permission to use plants from the Garden collections. B.J. P. gratefully acknowledges the support of an award from the Foundation for Polish Sciences (Start Programme).

Conflicts of interest The authors declare that they have no conflict of interest.

Open Access This article is distributed under the terms of the Creative Commons Attribution Noncommercial License which permits any noncommercial use, distribution, and reproduction in any medium, provided the original author(s) and source are credited.

\section{References}

Bohdanowicz J (1987) Alisma embryogenesis: the development and ultrastructure of the suspensor. Protoplasma 137:71-83

Bronner R (1975) Simultaneous demonstration of lipid and starch in plant tissues. Stain Technol 50(1):1-4

Cass DD, Karas I (1974) Ultrastructural organization of the egg of Plumbago zeylanica. Protoplasma 81:49-62

Chamberlin M, Horner HT, Palmer RG (1993) Nutrition of ovule embryo sac and young embryo in soybean: an anatomical and autoradiographic study. Can J Bot 71:1153-1168

Clutter ME, Sussex JM (1968) Ultrastructural development of bean embryo cells containing polytene chromosomes. J Cell Biol 39:26

Clutter ME, Sussex JM, Walbot V (1972) Rates of RNA and DNA synthesis in embryos and suspensors of Phaseolus coccineus. Am J Bot 59:648-649

Eggli U (2003) Illustrated handbook of succulent plants. Springer, Berlin, pp 423-467

Gunning BES, Pate JS (1969) "Tansfer cells" — plant cells with wall ingrowths, specialized in relation to short distance transport of solutes - their occurrence, structure, and development. Protoplasma 68:107-133

Gunnung BES, Pate JS (1974) Transfer cells. In: Robards AW (ed) Dynamic aspects of plant ultrastructure. McGraw-Hill, London, pp $441-480$

Gunning BES, Steer MW (1975) Ultrastructure and biology of plant cells. Edward Arnold, London

Heslop-Harrison Y (1977) The pollen-stigma interaction: pollen tube penetration in Crocus. Ann Bot 41:913-922
Jensen WA (1962) Botanical histochemistry. Freeman, San Francisco

Johansson M, Walles B (1993) Functional anatomy of the ovule in broad bean (Vicia faba L.). II. Ultrastructural development up to early embryogenesis. Int J Plant Sci 154(4):535-549

Johri BM, Ambegaokar KB (1992) Comparative embryology of angiosperms. Springer Verlag, Berlin

Jones MGK, Northcote DH (1972) Nematode induced syncytium-a multinucleate transfer cell. J Cell Sci 10:789-809

Kozieradzka-Kiszkurno M (2003) Development, ultrastructure and cytochemistry of embryo-suspensor in Sedum acre L. (Crassulaceae). $\mathrm{PhD}$ dissertation, University of Gdańsk, Gdańsk (in Polish)

Kozieradzka-Kiszkurno M, Bohdanowicz J (2006) Development and cytochemistry of the embryo suspensor in Sedum. Acta Biol Cracov Ser Bot 48:67-72

Kozieradzka-Kiszkurno M, Bohdanowicz J (2010) Unusual electrondense dome associates with compound plasmodesmata in the embryo-suspensor of genus Sedum (Crassulaceae). Protoplasma 247:117-120. doi:10 1007/s00709-010-0133-9

Kozieradzka-Kiszkurno M, Świerczyńska J, Bohdanowicz J (2010) Embryogenesis in Sedum acre L.: structural and immunocytochemical aspects of suspensor development. Protoplasma. doi:10.1007/s00709-010-0248-Z

Kozieradzka-Kiszkurno M, Płachno BJ, Bohdanowicz J (2011) Are unusual plasmodesmata in the embryo-suspensor restricted to species from the genus Sedum among Crassulaceae? Flora. doi:10.1016/j.flora.2010.11.017

Lee YI, Yeung EC, Lee N, Chung MC (2006) Embryo development in the Lady's Slipper Orchid, Paphiopedilum delenatii, with emphasis on the ultrastructure of the suspensor. Ann Bot 98:1311-1319

Maheshwari P (1950) An introduction to the embryology of angiosperms. McGraw-Hill, New York

Malik CP, Singh MB, Thapar N (1977) Physiology of sexual reproduction: 4. Histochemical characteristic of suspensor of Brassica campestris. Phytomorphology 27:384-389

Marinos NG (1970) Embryogenesis of the pea (Pisum sativum): I. The cytological environment of the developing embryo. Protoplasma 70:261-279

Mauritzon J (1933) Studien über die Embryologie der Familien Crassulaceae und Saxifragaceae. Thesis, University of Lund, Lund

Mikesell J (1990) Anatomy of terminal haustoria in the ovule of plantain (Plantago major L.) with taxonomic comparison to other angiosperm taxa. Bot Gaz 151:452-464

Nagl W (1974) The Phaseolus suspensor and its polytene chromosomes. Z Pflanzenphysiol 73:1-44

Nagl W (1976) Early embryogenesis in Tropaeolum majus L.: ultrastructure of the embryo-suspensor. Biochem Physiol Pflanz 170:253-260

Nagl W (1977) "Plastolysomes" — plastids involved in the autolysis of the embryo-suspensor in Phaseolus. Z Pflanenphysiol 85:4551

Nagl W, Kühner S (1976) Early embryogenesis in Tropaeolum majus L.: diversification of plastids. Planta 133:15-19

Newcomb W, Fowke LC (1974) Stellaria media embryogenesis: the development and ultrastructure of the suspensor. Can J Bot 52:607-614

Pate JS, Gunning BES (1972) Transfer cells. Annu Rev Plant Physiol 23:173-196

Picciarelli P, Piaggesi A, Alpi A (1991) Gibberellins in suspensor, embryo and endosperm of developing seeds of Cytisus laburnum. Phytochemistry 30(6):1789-1792

Płachno BJ, Świątek P, Kozieradzka-Kiszkurno M (2010) The F-actin cytoskeleton in syncytia from non-clonal progenitor cells. Protoplasma. doi:10.1007/s00709-010-0209-6 
Ponzi R, Pizzolongo P (1973) Ultrastructure of plastids in the suspensor cells of Ipomoea purpurea. Roth J Submicr Cytol $5: 257-263$

Prabhakar K, Vijayaraghavan MR (1983) Histochemistry and ultrastructure of suspensor cells in Alyssum maritimum. Cytologia 48:389-402

Pritchard HN (1964) A cytochemical study of embryo development in Stellaria media. Am J Bot 51:472-479

Raghavan V (1997) Experimental embryogenesis in vascular plants. Academic, New York

Raghavan V (2006) Double fertilization - embryo and endosperm development in flowering plants. Springer, Berlin

Rodkiewicz B, Fyk B, Szczuka E (1994) Chlorophyll and cutin in early embryogenesis in Capsella, Arabidopsis, and Stellaria investigated by fluorescence microscopy. Sex Plant Reprod $7: 287-289$

Sangduen N, Kreitnen GL, Sorensen EL (1983) Light and electron microscopy of embryo development in perennial and annual Medicago species. Can J Bot 61:837-849

Schnepf E, Nagl W (1970) Über einige Struktubesonderheiten der Suspensorzellen von Phaseolus vulgaris. Protoplasma 69:133-143

Schulz SR, Jensen WA (1969) Capsella embryogenesis: the suspensor and the basal cell. Protoplasma 67:139-163

Schwartz BW, Vernon DA, Meinke DW (1997) Development of the suspensor: differentiation, communication and programmed cell death during plant embryogenesis. In: Vasil B (ed) Cellular and molecular biology of plant seed development. Kluwer, Dordrecht, pp 53-72

Shamrov II (2000) Translocation pathways for metabolites in developing ovules of Gentiana cruciata L., Gymnadenia conopsea (L.) R.Br., Gagea stipitata Merklin and Luzula pedemontana Boiss. et Reot. Acta Biol Cracov Ser Bot 42(1):61-77
Simoncioli C (1974) Ultrastructural characteristics of Diplotaxis erucoides (L.) DC. suspensor. Giorn Bot Ital 108:175-189

Singh AP, Bhalla PL, Malik CP (1980) Activity of some hydrolytic enzymes in autolysis of the embryo suspensor in Tropaeolum majus L. Ann Bot 45:523-527

Souéges R (1927) Développement de l'embryon chez le Sedum acre L. Bull Soc Bot Fr 74:234-251

Souéges R (1936) Modifications au tableau récapitulatif des lois du développement chez le Sedum acre L. Le type embryonomique de cette espéce chez les autres. Bull Soc Bot Fr 83:13-18

Spurr AR (1969) A low-viscosity epoxy resin embedding medium for electron microscopy. J Ultrastruct Res 26:31-43

Świerczyńska J, Bohdanowicz J (2003) Microfilament cytoskeleton of endosperm chalazal haustorium of Rhinanthus serotinus (Scrophulariaceae). Acta Biol Cracov Ser Bot 45:143-148

Tolbert NE (1971) Microbodies, peroxisomes and glyoxisomes. In: Machlis L (ed) Annual revive of plant physiology. Ann Rev Inc, California, 22:45-74

Tolbert NE, Essner E (1981) Microbodies: peroxisomes and glyoxysomes. J Cell Biol 91:271-283

Walbot V, Brady T, Clutter M, Sussex I (1972) Macromolecular synthesis during plant embryogeny: rates of RNA synthesis in Phaseolus coccineus embryos and suspensors. Dev Biol 29:104-111

Westafer JM, Brown RM Jr (1976) Electron microscopy of the cotton fibre: new observations on cell wall formation. Cytobios 15:111-138

Ye XL, Zee SY, Yeung EC (1997) Suspensor development in the Nun orchid, Phaius tankervilliae. Int J Plant Sci 158:704-712

Yeung EC, Clutter ME (1979) Embryogeny of Phaseolus coccineus: the ultrastructure and development of the suspensor. Can J Bot $57: 120-136$

Yeung EC, Meinke DW (1993) Embryogenesis in angiosperms: development of the suspensor. Plant Cell 5:1371-1381 